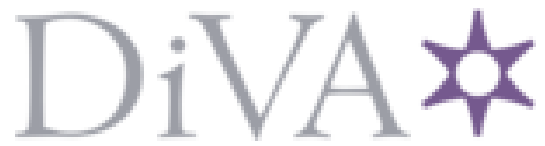

http://www.diva-portal.org

Preprint

This is the submitted version of a chapter published in Innovating Climate Governance: Moving Beyond Experiments.

Citation for the original published chapter:

Karvonen, A. (2018)

The city of permanent experiments?

In: Bruno Turnheim, Paula Kivimaa, and Frans Burkhout (ed.), Innovating Climate

Governance: Moving Beyond Experiments (pp. 201-215). Cambridge: Cambridge

University Press

https://doi.org/10.1017/9781108277679

N.B. When citing this work, cite the original published chapter.

Permanent link to this version:

http://urn.kb.se/resolve?urn=urn:nbn:se:kth:diva-219068 


\title{
The City of Permanent Experiments? Andrew Karvonen
}

\begin{abstract}
Over the last decade, a multitude of urban climate change experiments have emerged to go beyond traditional role of the state in environmental governance. These activities provide a real world evidence base for how a low-carbon world could be realised and they have the potential to fundamentally change the way that cities are conceived, built, and managed. Most urban climate change experiments are designed to be geographically and temporally bounded to accelerate innovation activities and realise actual changes on the ground. But what if urban experiments did not scale up? What if, instead of informing existing modes of urban governance, they became the dominant approach to governing cities? What would a 'city of permanent experiments' look like and how would it function? This chapter speculates on the implications of experimentation as the new mode of governance for twenty-first century cities. Here, experiments are not interpreted as one-off trials to provide evidence and justification for new low-carbon policies, regulations, and service provision; instead, they are emerging as a new mode of governance in themselves. This emerging form of urban governance is characterised by uncertainty, recursive learning processes, and spatial fragmentation with multiple unknown implications on the politics of cities in the future.
\end{abstract}

\section{Keywords}

Uncertainty, learning loops, fragmentation, governance, scaling, smart cities, participation, democracy

\section{Introduction}

Over the last decade, a multitude of experiments has emerged to catalyse climate change transitions (Evans, 2011; Castán Broto \& Bulkeley, 2013; Evans \& Karvonen, 2014; Bulkeley et al., 2015). These experiments involve activities that go beyond traditional state activities of policy making, regulation, incentives, and collective service provision (Biermann \& Pattberg, 2008; Okereke et al., 2009; Hoffmann, 2011). This is evident in cities where climate change experiments feed on innovation and creativity "to reinvigorate and stretch traditional avenues of governance to face the multifaceted challenges posed by a changing climate" (Karvonen et al., 2014: 110). In effect, they provide a situated and real world evidence base for how a low-carbon world could be realised and they have the potential to fundamentally change the way that cities are conceived, built, and managed.

The majority of urban climate change experiments are designed to be geographically and temporally bounded. This suggests that "experiments are critical sites through which visions of low carbon cities are created, networks built and learning enacted" (Bulkeley \& Castán Broto (2013: 373, emphasis added). Experimental setups are constructed and operated in inscribed spaces that are variously labelled as urban laboratories, innovation districts, demonstration projects, and testbeds (Karvonen \& van Heur, 2014; Marvin \& Silver, 2016). Restricting the spatial and temporal reach of climate change experiments is useful to accelerate innovation activities and to realise actual changes on the ground (van Buuren et al., this volume). The outcomes of these experimental activities can then be assessed against their intended outcomes through processes of formal evaluation (Heiskanen \& Matchoss, this volume). If deemed successful, the findings can be upscaled and transferred to other locales through policy making, development, and management activities. And if deemed unsuccessful, the experiments can be revised and conducted anew or simply abandoned (Van Buuren et al., this 
volume). Thus, experiments serve as a tangible way to institutionalise and formalise climate change governance (Angelouvski \& Carmin 2011; Bulkeley \& Castán Broto, 2013).

But what if urban experiments did not scale up or travel to other locales? What if, instead of informing existing modes of urban governance, they became the dominant approach to governing cities? What would a 'city of permanent experiments' look like and how would it function? This chapter explores the implications of experimentation as the new mode of governance for twenty-first century cities. Specifically, it is argued here that experiments might not simply serve as one-off trials to provide evidence and justification for new low-carbon policies, regulations, and service provision through existing circuits of policymaking and regulation. Instead, these activities are emerging as a new mode of governance in themselves (Sabel \& Zeitlin, 2008, 2010; Bulkeley et al., 2015). Castán Broto and Bulkeley (2013: 1947) argue that experiments "serve as potentially powerful means to create new forms of governing everyday life and city circulations, simultaneously reinforcing and reinventing the landscape of governance."

By moving away from notions of upscaling and transfer of experimental outcomes, this chapter points towards an emerging form of urban governance characterised by the embrace of uncertainty and contingency, the fostering of recursive learning processes, and the increasing spatial fragmentation of cities into experimental districts. This speculative inquiry is not intended as a forecast or prognostication. Instead, it is an attempt to reflect on the larger meaning of experimental practices and where these activities could potentially lead if they continue to propagate and become the dominant mode of climate governance. Of particular interest is the qualities of experiments and how they challenge and will potentially alter the future trajectory of cities in both intended and unintended ways. Such an emerging 'city of permanent experiments' has a number of significant implications on the politics of twenty-first century urban development.

\section{The Allure of Urban Experimentation}

Experimentation is an enticing twenty-first century response to a range of contemporary crises, ranging from climate change and global financial collapse to widespread social unrest and religious extremism. The appeal of experimentation lies in its promise to introduce new conceptions and configurations to the evolution of cities (Karvonen \& van Heur, 2014). With respect to climate change, a wide range of public, private, and third sector actors are developing and conducting interventions to alter the sociotechnical function of energy, transport, food, manufacturing, healthcare, buildings, finance, and so on (Bulkeley \& Castán Broto, 2013; Bulkeley et al., 2015). As Evans and colleagues (2016: 2) note, "Smart cities, eco-cities, low carbon urbanism, urban living labs, happy cities and sustainable urban development all draw on the idea that experimentation can generate more liveable, prosperous and sustainable urban futures." Urban experiments embody both top-down and bottomup forms of organisation that involve multiple stakeholders with varying aims and objectives. A common thread of these activities is to provide visible and tangible interventions that demonstrate that action is being taken. Bulkeley and colleagues (2015: 50) note that "making experiments is an attempt to negotiate the perceived scale divide between the unfolding of the problem and the possibilities of intervention." These are normative and highly visible activities that promise improved urban futures.

The rising popularity of experimentation in recent years has led to the term being used as a synonym for almost any form of change or deviance from 'business as usual'. Gross (2010a: 66) notes that "the concept of experimentation comes to have the same meaning as development, complexity, interconnection, globalization and so comes to mean the same as virtually anything that is subject to change." To counter this trend, it is important to understand urban experimentation not simply as a set of ad hoc or novel activities that diverge from the status quo, but as situated and purposive modes 
of trialling new configurations of sociotechnical systems to develop knowledge to respond to a particular problem. Karvonen and van Heur (2014: 383) define urban experimentation as: “1) involving a specific set-up of instruments and people that 2) aims for the controlled inducement of changes and 3) the measurement of these changes." This more formalised definition of experimentation highlights the simultaneous actions of observation and intervention with a specific end goal in mind. Robust urban experiments follow the logic of the scientific method and are carefully planned and executed. They have an explicit aim of measuring the impact of the intervention and comparing this to existing or baseline conditions. This process of experimentation creates learning loops to inform new modes of climate governance (Collins \& Ison, 2009; Evans \& Karvonen, 2011).

In addition, it is commonly assumed that the knowledge generated from experiments is intended to be scaled up both temporally and spatially (Brown \& Vergragt, 2008; Evans, 2011; Nevens et al., 2013; Bulkeley et al., 2015). Evans and colleagues (2016: 4) argue that "part of the allure of experimentation is based on the assumption that it is possible to scale up from an individual project to the city through a process of trialling, learning and rolling out." Thus, it is the outcomes of these experiments that have the greatest importance as they are translated into policy and regulatory frameworks and other existing modes of governance. But what if experiments, rather than informing existing modes of urban governance, were an end in themselves? What if experiments embodied a new form of urban governance? Bulkeley and colleagues (2015: 243) argue that "rather than being a matter of scaling up experimentation, its transformative potential comes through the traction generated by refashioning existing socio-technical configurations by translating between climate governmentalities and existing forms of social and material order." It is here that experimentation emerges as a new authority for climate change mitigation and adaptation activities. Experiments become embedded in climate change activities not through scaling and transfer but through the gradual replacement of existing modes of governance. This points towards an emerging 'city of permanent experiments' with significant implications on how urban development unfolds.

The following sections consider three potential achievements of experimental governance: 1) the embrace of uncertainty and contingency, 2) the generation of recursive learning loops, and 3) the fragmentation of the city into districts of innovation. Taken as a whole, these qualities of urban experiments suggest a new epistemology of urban governance that emphasises situated knowledge generation and action with unclear outcomes.

\section{Embracing Uncertainty}

Uncertainty is a defining characteristic of climate governance in cities, both in defining the problem at hand as well as devising potential solutions. The scale and magnitude of climate change creates multiple contingencies that are simultaneously physical, social, political, and economic. Urban experiments provide a mechanism to embrace ignorance, surprise, and the unknown (Callon et al., 2009; Gross, 2010b; Kullman, 2013). As Karvonen and van Heur (2014: 387) note, "real-world experimentation is founded on the idea that one is compelled to act despite uncertainties and gaps in knowledge." Uncertainty acknowledges the provisional and dynamic character of urban evolution (Simone, 2013; Karvonen et al., 2014; Silver, 2014). Unlike conventional urban governance, experiments are open to and feed upon the messy and contingent character of policymaking (Meadowcroft, 1999, 2009). It is understood that this mess is where new low-carbon futures can be forged.

Such a perspective resonates with a range of contemporary theoretical debates including poststructuralism, pragmatism, Mode 2 Science, transdisciplinarity, applied innovation, and knowledge co-production (e.g., Gibbons et al., 1994; Nowotny et al., 2001; Ramadier, 2004; Benneworth et al., 
2010; Evans \& Karvonen, 2011). As Karvonen and colleagues (2014: 106) argue, “The appeal of experimentation lies in its ability to harness radical contingency in the service of urban development" (emphasis in original). Uncertainty then becomes a catalyst for action rather than a hindrance to urban development. Further, it embodies a "particular style of adaptive governance" (Evans, 2011: 255) that responds to "the emergent properties of the system" (Bulkeley \& Castán Broto, 2013: 366). Experimentation replaces the procedural character of urban policymaking in favour of agile and responsive interventions. This recasts climate governance as edgy and dynamic, acknowledging and embracing the risks and unknowns of urban development processes.

Of course, uncertainty is not restricted to urban climate change experiments. The last decade has witnessed the rise of precarious urban conditions involving temporary land use, the appropriation of vacant buildings, pop-up trucks and stores, energy and water precarities, and related dialogues (e.g. Neilsen \& Rossiter, 2008; Bishop \& Williams, 2012; Andres, 2013; Tonkiss, 2013; Németh \& Langhorst, 2014; Harris, 2015). The world as a whole seems to be moving towards more precarious states of existence as the durable edifices of twentieth century liberal democracy slowly crumble. However, experimentation contrasts with these other activities by championing instability and unpredictability as a constructive, productive characteristic to reconfigure sociotechnical systems. The unknown is an opportunity to develop new ideas and approaches. There are strong parallels here with well-known alternative eco-settlements such as Arcosanti (USA), Auroville (India), Findhorn (Scotland), and ZEGG (Germany) (see Miles, 2007; Pickerill \& Maxey, 2009; Vanolo, 2013; Pickerill, 2016).

Christiania in Denmark is perhaps the most famous of these alternative eco-settlements. Initiated in 1971 on 34 hectares in Greater Copenhagen as a hippy community, the neighbourhood has evolved as a centre for social activism and lifestyles to counter mainstream capitalist society (Conroy, 1994; Vanolo, 2013). The urban settlement consists of about 400 buildings and around 1000 residents and supports social services such as health care, schools, and a post office as well as workshops for light industry and restaurants and bars. The settlement follows some local and national laws and regulations but much of day-to-day life is shaped through self-governance and participatory democracy. Vanolo (2013: 1789) notes that "the internal governance structure of Christiania is inspired by ideas of collective self-government and direct democracy, so that relevant decisions are always taken by consensus and after protracted discussion and negotiation in thematic meetings." It is this emphasis on self-governance that informs the settlement's character of precarity and fluidity. The status of Christiania (and the other eco settlements noted above) is constantly being negotiated and reworked to reflect the needs and desires of the residents.

In many ways, urban climate change experiments bring the ethos if not the politics of eco-settlements to conventional urban development; they reinforce uncertainty as an unavoidable and generative characteristic of the urban experience. A city of permanent experiments is thus a provisional achievement and one that is always 'in the making'. This also connects to recent theoretical contributions on assemblage theory and sociotechnical urban systems (Anderson \& McFarlane, 2011; Brenner et al., 2011; Farías, 2011; McFarlane, 2011b; Gopakumar, 2014) that recognises that cities do not have an end point but are always unfolding and evolving, they are processes rather than products. As McFarlane (2011b: 650) notes, the city here is understood as a "gathering process" rather than an end state. This fluidity of urbanisation involves the continual reassembly of sociotechnical metabolisms and the city of permanent experiments recognises governance as an activity of continually negotiating and responding to contemporary pressures and opportunities. However, this embrace of fluidity raises significant questions about the agency of various urban stakeholders. What competencies and skills are required to nurture this ever-changing state of the urban? How is uncertainty put to work to realise alternative futures? Who is held accountable and how? 


\section{Developing Learning Loops}

The embrace of uncertainty suggests that a city of permanent experiments has particular implications on flows of knowledge. Evans and Karvonen (2014: 426) note that experimentation involves "empiricising the urban landscape through monitoring and instrumentation, and then materializing these empirics by feeding them into subsequent planning policy that will shape urban development." The measurement and assessment of collected data provides situated, real world feedback about the performance of an intervention for transport, energy, water, and so on. This involves the development of reflexive governance approaches that are informed by monitoring and assessment. One of the principal benefits of urban climate change experiments is that they instil recursive learning into the governance of cities. Karvonen and colleagues (2015:105) argue that "experiments suggest recursive learning as a key component of enacting different urban futures." If, as McFarlane (2011a: 360) argues, the "city is a machine for learning", then experiments serve as the metaphorical sparkplug to generate an evidence base to inform decisions about urban development. This builds upon notions of 'reflexive modernity' (Beck, 1995) to realise formal modes of learning and response that can catalyse urban transformations.

With experiments, measurement and assessment is formalised as a process to support or contest various knowledge claims and discursive positions about the future of cities (Bulkeley \& Castán Broto, 2013). This provides new insights about cities that can be used to steer urban development (Karvonen et al., 2014). The empirical character of urban climate change experiments feeds into evidence-based policy activities where the governance of the city is informed by a robust base of findings rather than ideology (Sanderson, 2002). This is commonplace in the justification for smart urban development projects. Ubiquitous sensor networks are proposed to provide massive datasets to produce new understandings of urban function. These datasets provide instantaneous as well as long-term evidence base while creating a continuous process of learning and feedback to optimise and manage the sociotechnical metabolism of cities.

A contemporary example of the creation of continuous feedback loops is the futuristic smart city development of Songdo in South Korea (Lindsay, 2010; Halpern et al., 2013; Kshetri et al., 2014; Carvalho, 2015). Songdo was initiated by the national government as a new development in the early 2000 s as a 600 -hectare international business district located 65 kilometres southwest of Seoul. The project is distinctive because it is an early example of applying a ubiquitous sensor network in a city. The local authority, in collaboration with Cisco, installed thousands of sensors in the built environment that feed data into a control centre. Technicians can control energy, transportation, water, and other collective services in real time, creating a form of responsive urban governance. Reflecting on Songdo, Halpern and colleagues (2013) describe an emergent form of 'test-bed urbanism' where data collection, analysis, and response are completely automated. This points towards a new epistemology of the city where "self organization is its dominant rationality" (Halpern et al., 2013: 291). Self-regulation and self-adjustment become the end goal of urban learning loops, creating a city that is managed and steered by continuous short-term feedback rather than prescribed long-term planning. The rollout of fully sensored and algorithmic cities is several decades away but the possibilities of data-led urban development are beginning to emerge in various smart cities and point to how recursive learning might become an automated process in the future.

The emergence of learning loops again raises a number of questions. Who is involved in collecting and interpreting the data? What is done with the results? Does this reinforce the primacy of the expert as the ultimate arbiter of urban environmental governance? Are there ways to make learning loops more democratic and transparent? 


\section{Fragmenting the City}

In addition to creating learning loops and embracing uncertainty, the city of permanent experiments has important spatial implications. A small number of urban experiments encompass an entire city or region (e.g., Masdar City and Songdo) but most are conducted at a more limited scale to accelerate innovation and delimit risk. Karvonen and colleagues (2014: 104-5) argue that "the allure of the experiment lies in its ability to be radical in ambition while being limited in scope." Designated spaces of innovation including urban and living laboratories, low-carbon districts, testbeds, innovation zones, special purpose zones, and demonstration sites (Graham \& Marvin, 2001; Karvonen \& van Heur, 2014; Evans et al., 2015; Voytenko et al., 2016). The emphasis on districts focuses on the unique sociotechnical configurations of a particular context and provides real world sites of demonstration that can be visited and experienced first-hand (Shapin \& Shaffer, 1985; Reno, 2011; Späth \& Rohracher, 2012).

This emphasis on districts as the principal spatial unit of experiments has important implications on climate change governance. Cities here are defined not as holistic entities but as composites or agglomerations of bounded spaces defined by the extent of their experimental reach. This resonates with interpretations of cities as a collection of quarters, neighbourhoods, or villages (Neal, 2003; Bell \& Jayne, 2004; Roodhouse, 2010). However, rather than creating a tidy and rational agglomeration of districts akin to a patchwork quilt, urban climate change experiments is more likely to create a landscape of overlaps and gaps. This is because their boundaries are defined by knowledge generation activities rather than political, physical, or social attributes. Within the city of permanent experiments, there is no conscious attempt to knit the city together into a seamless whole. The challenge of urban (climate) governance then involves managing or orchestrating the experiments within the districts as well as negotiating the boundaries, overlaps, and gaps between districts (see Hölscher et al., this volume). Steering urban development involves engaging with the messiness of multiple experiments in an attempt to harmonise these activities. This raises significant issues about those existing urban service networks that transcend experimental boundaries (mass transit systems and roads, water and sewer networks, electricity supply, etc.) and their connection to experimental activities.

There is an intriguing historical parallel here with the rise of privatised collective service provision in the nineteenth century when entrepreneurs introduced competing infrastructure networks of water, sewer and electricity. These competing service networks were eventually replaced by natural monopolies that were often publicly owned and managed to realise the modern infrastructural ideal (Graham \& Marvin, 2001). With urban climate change experiments, there is the potential to return to the 'Wild West' of urban service provision through the creation of messier 'post-networked' cities of the twenty-first century (Coutard \& Rutherford, 2011, 2016). The emphasis on districts defined by experimental reach has the potential to increase social polarisation and economic disparity by favouring some districts with greater potential to address climate change mitigation and adaptation while neglecting others. And it also points to greater challenges in conceptualising and understanding cities as layered, fragmented, overlapping, and messy.

More optimistically, the downscaling to districts hints at the potential for more face-to-face deliberation over the day-to-day and long-term functioning of cities. Innovation districts could potentially foster more familiarity and interaction between stakeholders through participation in geographically bounded interventions. Moreover, this could bring climate change 'closer to home' by making experiments a normalised part of daily urban life (Castán Broto \& Bulkeley, 2013). Experimentation is not an activity that is applied to urban residents but is something achieved through their input. This bottom up form of urban development is personified in grassroots 
experiments, co-housing projects, Transition Towns, community energy initiatives, and related movements (Middlemiss \& Parrish, 2010; Chatterton, 2013, 2016; Feola \& Nunes, 2014). The aim is to leverage communities of residents to effect change and in the process, create a new polity (Walker, 2011; Karvonen, 2016).

A contemporary example of this is Ashton Hayes, a village of 900 people in Northwest England. In 2005, the villagers developed a bottom-up approach to climate governance to realise a shared goal of becoming England's first carbon neutral community (Alexander et al., 2007; AHGCN, 2017).

Eschewing input from their national and local governments, many (but not all) of the residents participate in collective efforts to reduce their carbon emissions through programmes of behavioural change, the establishment of a community energy company, and the fostering of local business development. Alexander and colleagues (2007: 71) conclude that "the carbon neutral project has enhanced the capacity of the Ashton Hayes community for self-management and self-reliance." Of particular importance is the door-to-door surveys conducted by volunteers on a periodic basis to monitor carbon reduction progress over time. Examples such as Ashton Hayes suggest that the city of permanent experiments has the potential to downscale climate change activities and in the process, create spaces for more participatory forms of political deliberation and action. However, these grassroots activities do not emerge on their own. They require leadership and organisation just like any other form of governance; the major difference here is that it comes from the residents rather than from the local government.

There are a number of questions that arrives with the reconfiguration of cities into experimental districts. How do the districts connect to one another? Is there a role for local and regional government bodies? What is to be done with districts where no experiments are being undertaken or where these is no polity to carry them out? How are infrastructure networks that bridge multiple districts governed?

\section{The City of Permanent Experiments}

The twentieth century era of city building is famously summarised in Daniel Burnham's proclamation "Make no little plans; they have no magic to stir men's blood" (see Gleeson, 2012). While there continue to be ambitious and high-profile projects to realise the twenty-first century city, the emergence of urban experiments points towards small scale, tentative interventions that incrementally shape urban development. In effect, experiments are the 'little plans' that Burnham warned us about over a century ago. This counters the reliance of conventional urban development on ambitious, comprehensive, and long-term planning. Instead, reinventing cities involves the embrace of uncertainty, the development of learning loops, and a focus on districts. Where it is typically assumed that climate change experiments inform and influence existing urban governance processes through processes of scaling and transfer, the city of permanent experiments suggests that experimentation is an end in itself. Bulkeley and Castán Broto (2013: 363) argue that "such interventions are a critical means through which governing as normal takes place." This embodies new forms of governance that are reflexive, responsive, and spatially delineated.

This 'institutionalisation' of experimentation as a form of reflexive governance has significant political implications (Hoffman, 2011; Bulkeley \& Castán Broto, 2013; Karvonen et al., 2014; Bulkeley et al., 2015; Evans et al., 2016). This emerging form of politics is neither inherently progressive nor regressive. While there is great potential for experiments to provide "grist in the urban mill, creating conflict, sparking controversy, offering the basis for contested new regimes of practice" (Bulkeley \& Castán Broto, 2013: 367-8), these activities can also be used to reproduce and extend existing modes of neo-liberal and capitalist modes of urban development. The politics of climate change experiments 
are ultimately determined by the context of these activities, the range of stakeholders involved, and the ways in which the experiments are carried out.

Of particular interest to the politics of urban climate change experiments is the potential for experiments to enhance democratic participation in urban governance. The focus on the district scale suggests the opportunity to develop more discursive and participatory forms of governance through situated activities with multiple stakeholders. However, it is important to question who is allowed to take part in both the institutional and practical activities of experimentation (Meadowcroft, 2009; Evans et al., 2016). The rise of co-production as a driver for urban sociotechnical transitions, as featured in urban living labs, emphasises the need to include all stakeholders in decisions about how cities evolve and change over time. As Evans and colleagues (2015:1) write, "Co-production involves stakeholders understanding each others' contexts, in order to work together to frame research that delivers more effective solutions." This suggests that experimentation has the potential to benefit from collective urban governance that brings together multiple voices (Voytenko et al., 2016) while also addressing the democratic deficit of contemporary urban politics.

On the other hand, these activities of co-production could simply validate predetermined agendas under the guise of democratic deliberation (Laurent, 2011). Thus, it is unclear if experiments provide a platform for controversies and differences to be deliberated and debated or if they are simply a means to reinforce the status quo (Karvonen et al., 2014). This suggests that there is a need to shift our collective gaze away from experimental activities and towards the stakeholders who are designing and conducting the experiments as well as those individuals and organisations that are using the experimental outcomes to affect change. It is through such a reflective and expansive consideration of urban climate change experiments as a political endeavour that we can assess their broader implications on urban development.

Ultimately, it is important to pay attention to this emerging agenda of urban climate change experimentation because it has the potential to transform urban governance and politics in ways that are yet to be determined. Reflecting on the ubiquitous sensing agenda in Songdo, Halpern and colleagues (2013: 300) ominously conclude that "these experiments will concern us long before their outcome is clear." Whether we are shortening the timeframes of urban planning, creating feedback loops of learning, providing an arena for inclusive deliberation and decision making, or reinforcing existing trends of neo-liberal capitalism and globalisation, experimentation appeals to a wide range of urban stakeholders for disparate (and sometimes contradictory) reasons. These activities introduce particular modes of governance with significant long-term implications (McFarlane, 2011b; Bulkeley \& Castán Broto, 2013). A fundamental challenge of experimentation is "to bring people and infrastructures together in ways that are capable of realising significantly different and more sustainable urban futures in socially just and democratic ways" (Evans et al., 2016: 10). As such, urban climate change experiments are not simply a curiosity or a fleeting moment in the history of cities but provides a glimpse of how the future of urban development.

\section{References}

Alexander, R., Hope, M. \& Degg, M. (2007). Mainstreaming sustainable development-a case study: Ashton Hayes is going carbon neutral. Local Economy, 22, 62-74.

Anderson, B. \& McFarlane, C. (2011). Assemblage and geography. Area, 43, 124-127.

Andres, L. (2013). Differential spaces, power hierarchy and collaborative planning: A critique of the role of temporary uses in shaping and making places. Urban Studies, 50, 759-775.

Angelovski, I. \& Carmin. J. (2011). Something borrowed, everything new: Innovation and institutionalization in urban climate governance. Current Opinion in Environmental Sustainability, 3, 169-175.

Ashton Hayes Going Carbon Neutral [AHGCN]. (2017). Ashton Hayes Going Carbon Neutral website, http:// www.goingcarbonneutral.co.uk, last accessed 6 February 2017. 
Beck, U. (1995). Ecological Enlightenment: Essays on the Politics of the Risk Society. Atlantic Highlands, NJ: Humanities Press.

Bell, D. \& Jayne, M. (eds). (2004). City of Quarters: Urban Villages in the Contemporary City. London: Ashgate.

Benneworth, P, Charles, D. \& Madanipour, A. (2010). Building localized interactions between universities and cities through university spatial development. European Planning Studies, 18, 1611-1629.

Biermann, F. \& Pattberg, P. (2008). Global environmental governance: Taking stock, moving forward. Annual Review of Environment and Resources, 33, 277-294.

Bishop, P. \& Williams, L. (2012). The Temporary City. London: Routledge.

Brenner, N., Madden, D.J. \& Wachsmuth, D. (2011). Assemblage urbanism and the challenges of critical urban theory. City, 15, 225-240.

Brown, H.S. \& Vergragt. P.J. (2008). Bounded socio-technical experiments as agents of systemic change: The case of a zero-energy residential building. Technological Forecasting and Social Change, 75, 107-130.

Bulkeley, H. \& Castán Broto, V. (2013). Government by experiment? Global cities and the governing of climate change. Transactions of the Institute of British Geographers, 38, 361-375.

Bulkeley, H., Castán Broto, V. \& Edwards, G.A.S. (2015). An Urban Politics of Climate Change: Experimentation and the Governing of Socio-Technical Transitions. London: Routledge.

Callon, M., Lascoumes, P. \& Barthe, Y. (2009). Acting in an Uncertain World: An Essay on Technical Democracy. London: The MIT Press.

Carvalho, L. (2015). Smart cities from scratch? A socio-technical perspective. Cambridge Journal of Regions, Economy and Society, 8, 43-60.

Castán Broto, V. \& Bulkeley, H. (2013). Maintaining climate change experiments: Urban political ecology and the everyday reconfiguration of urban infrastructure. International Journal of Urban and Regional Research, 37, 1934-1948.

Chatterton, P. (2013). Towards an agenda for post-carbon cities: Lessons from Lilac, the UK's first ecological, affordable cohousing community. International Journal of Urban and Regional Research, 37, 1654-1674.

Chatterton, P. (2016). Building transitions to post-capitalist urban commons. Transactions of the Institute of British Geographers, 41, 403-415.

Collins, K. \& Ison, R. (2009). Jumping off Arnstein's ladder: Social learning as a new policy paradigm for climate change adaptation. Environmental Policy and Governance, 19, 358-373.

Conroy, A. (1994). Christiania: The Evolution of a Commune. Amsterdam: International Institute of Social History.

Coutard, O. \& Rutherford, J. (2011). The rise of post-networked cities in Europe? Recombining infrastructural, ecological and urban transformations in low carbon transitions. In H. Bulkeley, V. Castán Broto, M. Hodson \& S. Marvin (eds) Cities and Low Carbon Transitions, pp. 106-125. London: Routledge.

Coutard, O. \& Rutherford, J. (2016). Beyond the networked city: An introduction. In O. Coutard \& J. Rutherford (eds) Infrastructure Reconfigurations and Urban Change in the North and South, pp. 1-25. London: Routledge.

Evans, J.P. (2011). Resilience, ecology and adaptation in the experimental city. Transactions of the Institute of British Geographers, 36, 223-237.

Evans, J., Jones, R., Karvonen, A., Millard, L. \& Wendler, J. (2015). Living labs and co-production: university campuses as platforms for sustainability science. Current Opinion in Environmental Sustainability, 16, 1-6.

Evans, J. \& Karvonen, A. (2011). Living laboratories for sustainability: Exploring the politics and epistemology of urban transition. In H. Bulkeley, V. Castán Broto, M. Hodson, \& S. Marvin (eds), Cities and Low Carbon Transitions, pp. 126-141. London: Routledge.

Evans, J. \& Karvonen, A. (2014). “Give me a laboratory and I will lower your carbon footprint!" Urban laboratories and the pursuit of low carbon futures. International Journal of Urban and Regional Research, 38, 413-30.

Evans, J., Karvonen, A. \& Raven, R. (2016). The experimental city: New modes and prospects of urban transformation. In J. Evans, A. Karvonen \& R. Raven (eds) The Experimental City, pp. 1-12. London: Routledge.

Farías, I. (2011). The politics of urban assemblages. City, 15, 365-374.

Feola, G. \& Nunes, R. (2014). Success and failure of grassroots innovations for addressing climate change: The case of the Transition Movement. Global Environmental Change, 24, 232-250. 
Gibbons, M., Limoges, C., Nowotny, H., Schwartzman, S., Scott, P. \& Trow, M. (1994). The New Production of Knowledge: The Dynamics of Science and Research in Contemporary Societies. Thousand Oaks, CA: Sage.

Gleeson, B. (2012). 'Make No Little Plans': Anatomy of planning ambition and prospect. Geographical Research, 50, 242-255.

Gopakumar, G. (2014). Experiments and counter-experiments in the urban laboratory of water-supply partnerships in India. International Journal of Urban and Regional Research, 38, 393-412.

Graham, S. \& Marvin, S. (2001). Splintering Urbanism: Networked Infrastructures, Technological Mobilities, and the Urban Condition. London: Routledge.

Gross, M. (2010a). The public proceduralization of contingency: Bruno Latour and the formation of collective experiments. Social Epistemology, 24, 63-74.

Gross, M. (2010b). Ignorance and Surprise: Science, Society, and Ecological Design. London: The MIT Press.

Halpern, O., LeCavalier, J., Calvillo, N. \& Pietsch, W. (2013). Test-bed urbanism. Public Culture, 25, 271-306.

Harris, E. (2015). Navigating pop-up geographies: Urban space-times of flexibility, interstitiality and immersion. Geography Compass, 9, 592-603.

Hoffmann, M.J. (2011). Climate Governance at the Crossroads: Experimenting with a Global Response after Kyoto. Oxford: Oxford University Press.

Karvonen, A. (2016). Low-carbon devices and desires in community housing retrofit. In H. Bulkeley, J. Stripple, \& M. Patterson (eds) Towards a Cultural Politics of Climate Change: Devices, Desires and Dissent, 51-65. Cambridge: Cambridge University Press.

Karvonen, A., Evans, J. \& van Heur, B. (2014). The politics of urban experiments: Radical change or business as usual?. In M. Hodson \& S. Marvin (eds) After Sustainable Cities?, 104-115. London: Routledge.

Karvonen, A. \& van Heur, B. (2014). Urban laboratories: Experiments in reworking cities. International Journal of Urban and Regional Research, 38, 379-392.

Kshetri, N., Alcantara, L.L. \& Park, Y. (2014). Development of a smart city and its adoption and acceptance: The Case of New Songdo. Communications \& Strategies, 96, 113-145.

Kullman, K. (2013). Geographies of experiment/experimental geographies: A rough guide. Geography Compass, 7, 879-894.

Laurent, B. (2011). Technologies of democracy: Experiments and demonstrations. Science and Engineering Ethics, 17, 649-666.

Lindsay, G. (2010). Cisco's big bet on New Songdo: Creating cities from scratch. Fast Company Magazine, 1 February. Available online at: http:// www.fastcompany.com/1514547/ciscos-bigbet- new-songdo-creating-cities-scratch [Accessed 6 February 2017].

McFarlane, C. (2011a). The city as a machine for learning. Transactions of the Institute of British Geographers, 36, 360-376.

McFarlane, C. (2011b). The city as assemblage: dwelling and urban space. Environment and Planning D: Society and Space, 29, 649-671.

Marvin, S. \& Silver, J. (2016). The urban laboratory and emerging sites of urban experimentation. In J. Evans, A. Karvonen, \& R. Raven (eds) The Experimental City, pp. 47-60, London: Routledge.

Meadowcroft, J. (1999). Planning for sustainable development: What can be learned from the critics?. In M. Kenny \& J. Meadowcroft (eds) Planning for Sustainability, pp. 12-38. London: Routledge.

Meadowcroft, J. (2009). What about the politics? Sustainable development, transition management, and long term energy transitions. Policy Sciences, 42, 323-340.

Middlemiss, L. \& Parrish, B.D. (2010). Building capacity for low-carbon communities: The role of grassroots initiatives. Energy Policy, 38, 7559-7566.

Miles, M. (2007). Urban Utopias: The Built and Social Architectures of Alternative Settlements. London: Routledge.

Neal, P. (ed.). (2003). Urban Villages and the Making of Communities. London: Taylor \& Francis.

Neilson, B. \& Rossiter, N. (2008). Precarity as a political concept, or, Fordism as exception. Theory, Culture \& Society, 25, 51-72.

Németh, J. \& Langhorst, J. (2014). Rethinking urban transformation: Temporary uses for vacant land. Cities, 40, 143-150.

Nevens, F., Frantzeskaki, N. Gorissen, L. \& Loorbach, D. (2013). Urban transition labs: Co-creating transformative action for sustainable cities. Journal of Cleaner Production, 50, 111-122.

Nowotny, H., Scott, P. \& Gibbons, M. (2001). Re-thinking Science: Knowledge and the Public in an Age of Uncertainty. Malden, MA: Polity. 
Okereke, C., Bulkeley, H. \& Schroeder, H. (2009). Conceptualizing climate governance beyond the international regime. Global Environmental Politics, 9, 58-78.

Pickerill, J. 2016. Eco-Homes: People, Place and Politics. London: Zed Books.

Pickerill, J. \& Maxey, L. (2009). Geographies of sustainability: Low impact developments and radical spaces of innovation. Geography Compass, 3, 1515-1539.

Ramadier, T. (2004). Transdisciplinarity and its challenges: The case of urban studies. Futures, 36(4), $423-39$.

Reno, J. (2011). Managing the experience of evidence: England's experimental waste technologies and their immodest witnesses. Science, Technology \& Human Values, 36, 842-863.

Roodhouse, S. (2010). Cultural Quarters: Principles and Practice. Bristol: Intellect Books.

Sabel, C.F. \& Zeitlin, J. (2008). Learning from difference: The new architecture of experimentalist governance in the EU. European Law Journal, 14, 271-327.

Sabel, C.F. \& Zeitlin, J. (eds). (2010). Experimentalist Governance in the European Union: Towards a New Architecture. Oxford: Oxford University Press.

Sanderson, I. (2002). Evaluation, policy learning and evidence-based policy making. Public Administration, 80, 1-22.

Shapin, S. \& Schaffer, S. (1985). Leviathan and the Air-Pump: Hobbes, Boyle, and the Experimental Life. Princeton: Princeton University Press.

Silver, J. (2014). Incremental infrastructures: Material improvisation and social collaboration across post-colonial Accra. Urban Geography, 35, 788-804.

Simone, A.M. (2013). Cities of uncertainty: Jakarta, the urban majority, and inventive political technologies. Theory, Culture \& Society, 30, 243-263.

Späth, P. \& Rohracher, H. (2012). Local demonstrations for global transitions -Dynamics across governance levels fostering socio-technical regime change towards sustainability. European Planning Studies, 20, 461-479.

Tonkiss, F. (2013). Austerity urbanism and the makeshift city. City, 17, 312-324.

Vanolo, A. (2013). Alternative capitalism and creative economy: The case of Christiania. International Journal of Urban and Regional Research, 37, 1785-1798.

Voytenko, Y, McCormick, K., Evans, J. \& Schliwa, G. (2016). Urban living labs for sustainability and low carbon cities in Europe: Towards a research agenda. Journal of Cleaner Production, 123, 45-54.

Walker, G. (2011). The role for 'community' in carbon governance. Wiley Interdisciplinary Reviews: Climate Change, 2, 777-782. 